\title{
PKM PELATIHAN MENGENAL DAN MENGIDENTIFIKASI HOAXLKSA AR RIDHO RANGKAPAN JAYA, DEPOK
}

\author{
Wulan Yulian Anggini*, Laila Desnaranti, Febby Pratama Putra \\ Universitas Indraprasta PGRI \\ *angginiwulan10@gmail.com
}

\begin{abstract}
The development of information technology has caused the world to become borderless. The circulation of various information from the internet and social media without a filter makes hoaxes (fake news) easy to spread. This is a big concern for the community, moreover, hoaxes do not only affect adults but also students who are still teenagers. Teenagers are the young generation who are very close to social media. They consider social media is not only as entertainment, but also as an information center. Therefore, it is very important for teenagers to know and be able to distinguish hoaxes from an early age, so that they can always act and think critically with the information they receive. Teenagers need to be trained to digest the correct information so that hoaxes can be minimized day by day. Teenagers are not only have to know who made the news or information they read but also have to know the understanding of what messages are contained in the news. Because nowadays there is a lot of misleading news that ultimately ends up harming the development of adolescent thinking. It is important for teenagers to recognize legitimate and true news sites. Teenagers also need to be more careful about identifying low-quality content. This community service activity is in the form of training activities to recognize, identify, and distinguish hoaxes (fake news). The output targets generated from this community service activity are in the form of knowledge about the introduction, identification, and differences of hoaxes (fake news).
\end{abstract}

Keywords: teenagers; information; hoaxes

\begin{abstract}
Abstrak
Perkembangan teknologi informasi telah menyebabkan dunia menjadi seperti tanpa batas. Beredarnya berbagai informasi dari internet dan media sosial tanpa adanya sebuah filter membuat hoax (berita palsu) mudah sekali menyebar. Hal ini menjadi keresahan yang besar bagi masyarakat, terlebih lagi hoax tidak hanya menghinggapi orang dewasa tapi juga para pelajar yang notabene nya masih remaja. Remaja adalah generasi muda yang dekat sekali dengan media sosial. Mereka menganggap media sosial tidak hanya sebagai hiburan semata, melainkan pusat informasi. Oleh karena itu sangatlah penting bagi remaja mengetahui dan bisa membedakan hoax sejak dini, agar mereka selalu bisa bersikap dan berpikir kritis dengan informasi yang mereka terima. Remaja perlu dilatih untuk mencerna informasi yang benar agar semakin hari hoax bisa diminimalisir. Remaja tidak hanya harus mengetahui siapa yang membuat berita atau informasi yang mereka baca tapi juga harus mengetahui pemahaman mengenai pesan apa saja yang terkandung dalam berita tersebut. Karena saat ini banyak sekali berita yang menyesatkan yang pada akhirnya berujung merugikan perkembangan berpikir remaja. Penting bagi remaja untuk mengenali situssitus berita yang sah daan benar. Remaja juga harus lebih cermat mengenali konten-konten yang berkualitas rendah. Kegiatan pengabdian kepada masyarakat ini berupa kegiatan pelatihan mengenal, mengidentifikasi, dan membedakan hoax (berita palsu). Adapun target luaran yang dihasilkan dari kegiatan pengabdian pada masyarakat ini berupa pengetahuan tentang pengenalan, identifikasi, dan perbedaan hoax (berita palsu)

Kata Kunci: remaja; informasi; berita palsu
\end{abstract}

\begin{tabular}{l|l|l} 
Submitted: 2021-09-09 & Revised: 2021-10-11 & Accepted: 2021-10-26
\end{tabular}

\section{Pendahuluan}

Pada masa sekarang ini perkembangan teknologi informasi telah menyebabkan dunia menjadi seperti tanpa batas. Teknologi informasi saat ini selain memberikan kontribusi bagi peningkatan kesejahteraan, kemajuan, dan peradaban manusia sekaligus menjadi arena efektif perbuatan melawan hukum (Pomounda, 2015). Salah satu contoh pelanggaran hukum menggunakan teknologi informasi adalah penyebaran hoax (berita palsu). 
Hoax adalah artikel berita yang sengaja dibuat untuk menyesatkan pembaca. Ada 2 motivasi utama yang menyebabkan beredarnya berita palsu. Pertama adalah uang, artikel berita seolaholah menjadi virus di media sosial yang dapat menarik pendapatan iklan yang signifikan saat pengguna mengklik situs aslinya, kedua adalah ideologis. Beberapa penyedia berita palsu berusaha untuk memajukan kandidat yang mereka sukai (Allcott\&Genzkow, 2017)

Beredarnya berbagai informasi dari internet dan media sosial tanpa adanya sebuah filter, membuat hoax mudah sekali menyebar. Indonesia merupakan negara demokrasi terbesar ke-3 di dunia setelah India dan Amerika yang mengalami permasalahan serius soal penyebaran berita palsu (fake news/hoax). Pemerintah melalui Kepolisian Republik Indonesia telah mengeluarkan ancaman untuk memproses hukum pihak-pihak yang menyebarkan berita palsu (Firmansyah, 2017)

Hoax menjadi keresahan yang besar bagi masyarakat karena hoax tidak hanya menghinggapi orang dewasa tapi juga para pelajar yang notabene nya masih remaja. Remaja adalah generasi muda yang dekat sekali dengan media sosial. Mereka menganggap media sosial tidak hanya sebagai hiburan semata, melainkan pusat informasi. Oleh karena itu sangatlah penting bagi remaja mengetahui dan bisa membedakan hoax sejak dini, agar mereka selalu bisa bersikap dan berpikir kritis dengan informasi yang mereka terima.

Remaja perlu dilatih untuk mencerna informasi yang benar agar semakin hari hoax bisa diminimalisir. Remaja tidak hanya harus mengetahui siapa yang membuat berita atau informasi yang mereka baca tapi juga harus mengetahui pemahaman mengenai pesan apa saja yang terkandung dalam berita tersebut. Karena saat ini banyak sekali berita yang menyesatkan yang pada akhirnya berujung merugikan perkembangan berpikir remaja. Penting bagi remaja untuk mengenali situs-situs berita yang sah daan benar. Remaja juga harus lebih cermat mengenali konten-konten yang berkualitas rendah.

Peran masyarakat sangatlah diperlukan untuk turut serta melakukan pencegahan terhadap berita hoax. Pemerintah dan pihak Kepolisian Republik Indonesia pun secara tegas menindak hukum pihak-pihak yang menyebarkan hoax. Salah satu upaya yang dilakukan adalah memblokir situs internet (web) yang dinilai sebagai sumber hoax. Terkait kebijakan pemblokiran situs tersebut, pemerintah telah menegaskan bahwa dalam mengambil keputusan untuk memblokir situs tertentu pertimbangan utamanya adalah isi (content) dari situs yang bersangkutan bukan afiliasi politik pengelola situs tersebut (Siswoko, 2017)

Syarat berita yang baik adalah harus benar dan tepat (akurat), berita tersebut harus menarik, baru atau terkini, dan seimbang. Sebuah berita yang baik harus mengandung prinsip akurasi, jadi setiap informasi yang ada di dalam berita tersebut harus dipastikan bahwa benar dan tepat sesuai dengan apa yang terjadi. (Pratama, 2020). Salah satu cara untuk memerangi hoax adalah dengan melakukan edukasi kepada masyarakat khususnya remaja. Dibutuhkan media dan metode yang tepat dalam penyampaian materi hoax kepada remaja untuk menghasilkan generasi bebas hoax. Diperlukan juga adanya pelatihan untuk dapat mengenal dan mengidentifikasi hoax (berita palsu) dalam dunia digital karena dapat membantu para remaja, dalam hal ini khususnya remaja/anak asuh di LKSA Ar Ridho.

\section{Metode}

Tahap pertama dari kegiatan pengabdian kepada masyarakat ini yaitu observasi. Tim abdimas menanyakan dan mencari tahu kepada pengurus LKSA Ar Ridho perihal pelatihan apa yang saat ini benar-benar dibutuhkan oleh anak asuh. Tahap kedua adalah sosialisasi kepada para pengurus dan anak asuh di LKSA Ar Ridho yang nantinya akan menjadi peserta dalam kegiatan ini. Sosialisasi yang dilakukan meliputi perkenalan, pemaparan konsep kegiatan, susunan acara, serta praktek yang akan dilaksanakan pada saat kegiatan berlangsung. Tahap ketiga dalam kegiatan ini adalah kegiatan inti, yaitu pelatihan mengenal dan mengidentifikasi hoax (berita palsu). Kegiatan dipandu 
oleh tim abdimas yang berjumlah 3 orang dan dibantu oleh 1 mahasiswa. Mahasiswa membantu dalam proses menyiapkan daftar hadir, membantu menyiapkan alat yang dibutuhkan selama pelatihan, dan mendistribusikan konsumsi. Acara ini diikuti oleh anak asuh di LKSA Ar Ridho yang berjumlah 22 peserta. Acara ini di awali dengan pemaparan materi oleh tim abdimas, tanya jawab seputar bagaimana membedakan berita palsu, praktek identifikasi hoax, juga berbagi pengalaman antar anak asuh yang pernah mengalami seputar berita palsu. Tim memberikan contoh-contoh yang berita palsu yang sering ditemui dalam dunia digital dalam bentuk visual dan audiovisual.

\section{Hasil dan Pembahasan}

Kegiatan pengabdian masyarakat ini berawal dari niat dan keinginan untuk bisa membantu para anak asuh di LKSA Ar Ridho mengenal dan mengidentiikasi hoax yang saat ini menjadi hal yang harus diperangi dalam dunia digital. Pelatihan ini didasarkan pada keprihatinan terhadap tingginya hoax yang beredar di masyarakat. Remaja sebagai generasi yang sangat rentan terhadap dampak negatif yang ditimbulkan dalam dunia digital terutama hoax dan kejahatan siber lainnya, harus dibekali dengan pemahaman literasi digital yang sesuai dengan usia mereka. Oleh karena itu materi dalam pelatihan ini disusun dengan studi kasus pada anak usia remaja. Contoh yang digunakan untuk mengukur kemampuan anak asuh dalam memahami hoax berupa pilihan gambar, teks, dan video yang megindikasikan hoax dan bukan hoax.

Awalnya beberapa anak asuh merasa kesulitan dalam praktek mengidentifikasi hoax, hal ini terlihat saat tim abdimas melakukan tanya jawab. Tetapi karena pembahasan dilakukan langsung oleh tim, mereka mulai memahami dan perlahan mulai mampu mengidentifikasi dengan baik dan benar. Setelah hal ini dilakukan dalam beberapa sesi, para anak asuh mulai terlihat percaya diri dalam mengidentifikasi berita/artikel yang disajikan oleh tim penyaji. Respon yang didapatkan dalam kegiatan ini sangatlah baik, hal tersebut dapat terlihat dari antusias para anak asuh. Tim berharap dengan adanya kegiatan ini bisa membantu melatih anak asuh di LKSA Ar Ridho khususnya remaja agar bisa mengenal dan mengidentifikasi hoax yang nantinya diharapkan kedepannya bisa saling mengedukasi satu sama lain baik dalam satu lingkungan LKSA maupun lingkungan luar LKSA.

\section{Kesimpulan}

Hasil yang dicapai dalam kegiatan ini adalah para anak asuh mampu mengenal dan mengidentifikasi hoax dengan baik dan benar sesuai dengan usia mereka. Hal ini diharapkan bisa meningkatkan literasi para anak asuh agar kedepannya mereka tidak ikut menyebarkan hoax dan justru malah ikut melawan hoax yang sangat merajalela dalam dunia digital. Selain itu para anak asuh diberikan saran-saran untuk bisa meningkatkan literasi mereka dengan minimal membaca bacaan yang sudah disediakan dari pihak pengurus minimal 1 buku dalam 1 hari. Selanjutnya diharapkan LKSA Ar Ridho dapat selalu memberikan bimbingan secara rutin perihal literasi yang baik, terutama literasi digital agar para anak asuh yang sebagian besar adalah remaja bisa terhindar dari hoax.

\section{Daftar Pustaka}

Allcott, H., \& Gentzkow, M. (2017). Social media and fake news in 2016 election. Journal of Economic Perspective volume 31. Number 2, 211-236

Firmansyah, Ricky. (2017). Web klarifikasi berita untuk meminimalisir penyebaran berita hoax. Jurnal Informatika, vol 4 No.2, 230-235 
Pomounda, I. (2015). Perlindungan hukum bagi korban penipuan melalui media elektronik (suatu pendekatan viktimologi). Jurnal IImu Hukum Legal Opinion Edisi 4, Volume 3, 1-9.

Pratama, M.,I. (2020). Efek menonton tayangan video ciri-ciri berita hoaxs terhadap tingkat pengetahuan remaja tentang berita hoaxs. Interaksi Online vol.8 no.2 113-123

Siswoko, K. H. (2017). Kebijakan pemerintah menangkal penyebaran berita palsu atau 'hoax'. Jurnal Muara IImu Sosial, Humaniora, dan Seni Vol. 1, No. 1, April 2017, 13-19. 